\title{
Indeterminate RIBA results were associated with the absence of hepatitis C virus RNA (HCV-RNA) in blood donors
}

\author{
Felicidade Mota Pereira ${ }^{[1],[2],}$ Maria Alice Sant'ana Zarife ${ }^{[1]}$, Eliana Almeida Gomes Reis ${ }^{[2]}$ \\ and Mitermayer G. Reis ${ }^{[2],[3],[4]}$
}

[1]. Laboratório Central de Saúde Pública do Estado da Bahia, Secretaria da Saúde, Salvador, BA. [2]. Laboratório de Patologia e Biologia Molecular, Centro de Pesquisas Gonçalo Moniz, Fundação Oswaldo Cruz, Salvador, BA. [3]. Faculdade de Medicina da Bahia, Universidade Federal da Bahia, Salvador, BA. [4]. Escola Baiana de Medicina e Saúde Pública, Salvador, BA.

\begin{abstract}
Introduction: Hepatitis $\mathrm{C}$ virus (HCV) infection is diagnosed by the presence of antibodies and is supplemented by confirmatory testing methods, such as recombinant immunoblot assay (RIBA) and HCV-RNA detection. This study aimed to evaluate the efficacy of RIBA testing to diagnose HCV infection in blood donors positive for anti-HCV antibodies. Methods: A total of 102 subjects positive for anti-HCV determined by enzyme-linked immunosorbent assay (ELISA) at the Hematology and Hemotherapy Foundation of Bahia (HEMOBA) were later assessed with new samples using the Abbott Architect anti-HCV test (Abbott Diagnostics, Wiesbaden, Germany), the RIBA III test (Chiron RIBA HCV 3.0 SIA, Chiron Corp., Emeryville, CA, USA), the polymerase chain reaction (PCR; COBAS ${ }^{2}$ AMPLICOR HCV Roche Diagnostics Corp., Indianapolis, IN, USA) and line probe assay (LiPA - Siemens, Tarrytown, NY, USA) genotyping for HCV diagnosis. Results: Of these new samples, 38.2\% (39/102) were positive, $57.8 \%(59 / 102)$ were negative and 3.9\% (4/102) were indeterminate for anti-HCV; HCV-RNA was detected in $22.5 \%(23 / 102)$ of the samples. RIBA results were positive in $58.1 \%(25 / 43)$, negative in $9.3 \%(4 / 43)$ and indeterminate in $32.6 \%$ $(14 / 43)$ of the samples. The prevailing genotypes were $1(78.3 \%, 18 / 23), 3(17.4 \%, 4 / 23)$ and $2(4.3 \%, 1 / 23)$. All 14 samples with indeterminate RIBA results had undetectable viral loads (detection limit $\leq 50 \mathrm{IU} / \mathrm{mL}$ ). Of these samples, $71.4 \%(10 / 14)$ were reevaluated six months later. Eighty percent (8/10) of these samples remained indeterminate by RIBA, and 20\% $(2 / 10)$ were negative. Conclusions: In this study, individuals with indeterminate RIBA results had no detectable HCV-RNA.
\end{abstract}

Keywords: Blood donors. Hepatitis C virus. Anti-HCV. RIBA. HCV-RNA.

\section{INTRODUCTION}

The hepatitis $\mathrm{C}$ virus (HCV) is a worldwide public health concern, with an estimated $2.2 \%$ of the world population suffering from infection. This prevalence translates into roughly 130 million $\mathrm{HCV}$ carriers, with chronic infections occurring in approximately $70 \%$ of all cases ${ }^{1}$. A population-based national survey of viral hepatitis conducted in Brazilian capitals measured the HCV prevalence to be between $0.9 \%$ and $1.9 \%{ }^{2}$. In a populationbased study conducted in 1998 in Salvador, the capital of the northeastern State of Bahia, the HCV prevalence was $1.5 \%{ }^{3}$.

The laboratory diagnosis of HCV infection is generally performed with serological testing for anti-HCV antibodies or using molecular biological methods for HCV-RNA detection.

Address to: Dr. Mitermayer Galvão dos Reis. Lab. Patologia e Biologia Molecular/CPqGM/FIOCRUZ. Rua Waldemar Falcão 121, Candeal, 40296-710 Salvador, BA, Brasil.

Phone: 5571 3176-2205; Fax: 5571 3176-2327

e-mail: miter@bahia.fiocruz.br

Received 30 November 2013

Accepted 31 January 2014
Currently, alternative enzyme-linked immunosorbent assay (ELISA) methods, such as chemiluminescence assays (CLIAs) or microparticle enzyme immunoassays (MEIAs), which employ the same antigens as ELISAs, can be used to detect anti-HCV antibodies ${ }^{4}$. CLIA offers a significantly improved specificity and positive predictive value while maintaining a sensitivity that is comparable to ELISA ${ }^{5}$. False-positive results for anti$\mathrm{HCV}$ are likely in populations with a low $\mathrm{HCV}$ prevalence, such as blood donors, or in instances when cross-reactivity occurs due to the presence of other viral antigens or antibodies in individuals with immune disorders. False-negative results may occur in immunosuppressed populations, such as HIV-infected patients, solid organ transplant recipients, hypoglobulinemia or agammaglobulinemia patients or hemodialysis patients ${ }^{6,7}$.

The CDC (Centers for Disease Control and Prevention, Atlanta, GA, USA) recommends that all anti-HCV screening be confirmed using supplementary serological testing or NAT (nucleic acid testing). RIBA (recombinant immunoblot assay) is the preferred supplementary serological testing method due to its robust specificity. RIBA testing requires the identification of false-positive results using ELISA, particularly when considering populations with low HCV prevalence rates, such as blood donors, students and general populations lacking known risk factors ${ }^{8}$. RIBA detects the reactivity of antibodies 
to antigens that are immobilized on nitrocellulose immunoblot strips. When no reactions are observed against any of the evaluated antigens, a RIBA test is considered negative. When a reaction is registered against only one protein, it is then considered indeterminate. However, when reactivity is observed against two or more proteins, the result is considered positive ${ }^{9}$.

Indeterminate RIBA results have been observed in recently infected individuals who are undergoing the seroconversion process and occasionally in populations that are chronically infected with $\mathrm{HCV}$. Indeterminate outcomes may also result from false positives during screening, most commonly in populations at low risk for $\mathrm{HCV}$ infection ${ }^{10}$. The present study observed that indeterminate RIBA results were significantly associated with the absence of HCV-RNA, suggesting that this test may be unnecessary, particularly in low-risk populations, such as blood donors.

\section{METHODS}

\section{Study population}

A total of 62,123 samples from blood donors were screened at the Hematology and Hemotherapy Foundation of Bahia (HEMOBA) between June 1, 2009 and December 22, 2010 for
anti-HCV antibodies using ELISA and a HEPANOSTIKA ${ }^{\circledR}$ HCV Ultra assay kit with a DAVINCI ${ }^{\circledR}$ system microElisa instrument (Beijing United Biomedical Co., LTD.). Of these samples, $0.48 \%(298 / 62,123)$ tested positive, while $99.52 \%$ $(61,825 / 62,123)$ tested negative. We collected new samples from $34.2 \%$ (102/298) of the individuals who tested positive for anti-HCV by ELISA at the Hematology and Hemotherapy Foundation of Bahia (HEMOBA) for confirmatory HCV diagnosis. The protocols used in this study were approved by the Ethics and Research Institutional Review Board of the Oswaldo Cruz Foundation (FIOCRUZ-Bahia), case number 193/2009, protocol 294. All included patients underwent an interview, answered a questionnaire and provided written informed consent. Figure 1 depicts an illustration of the overall study design.

\section{Hepatitis $\mathrm{C}$ virus antibody detection and confirmatory RIBA testing}

All study participants were reassessed for the presence of anti-HCV antibodies at the Central Laboratory of Public Health of Bahia (LACEN-BA) using the ARCHITECT AntiHCV CLIA (Abbott Diagnostics, Wiesbaden, Germany) in an Architect i4000 (Abbott Diagnostics) automated immunology analyzer. All serological testing was performed and analyzed

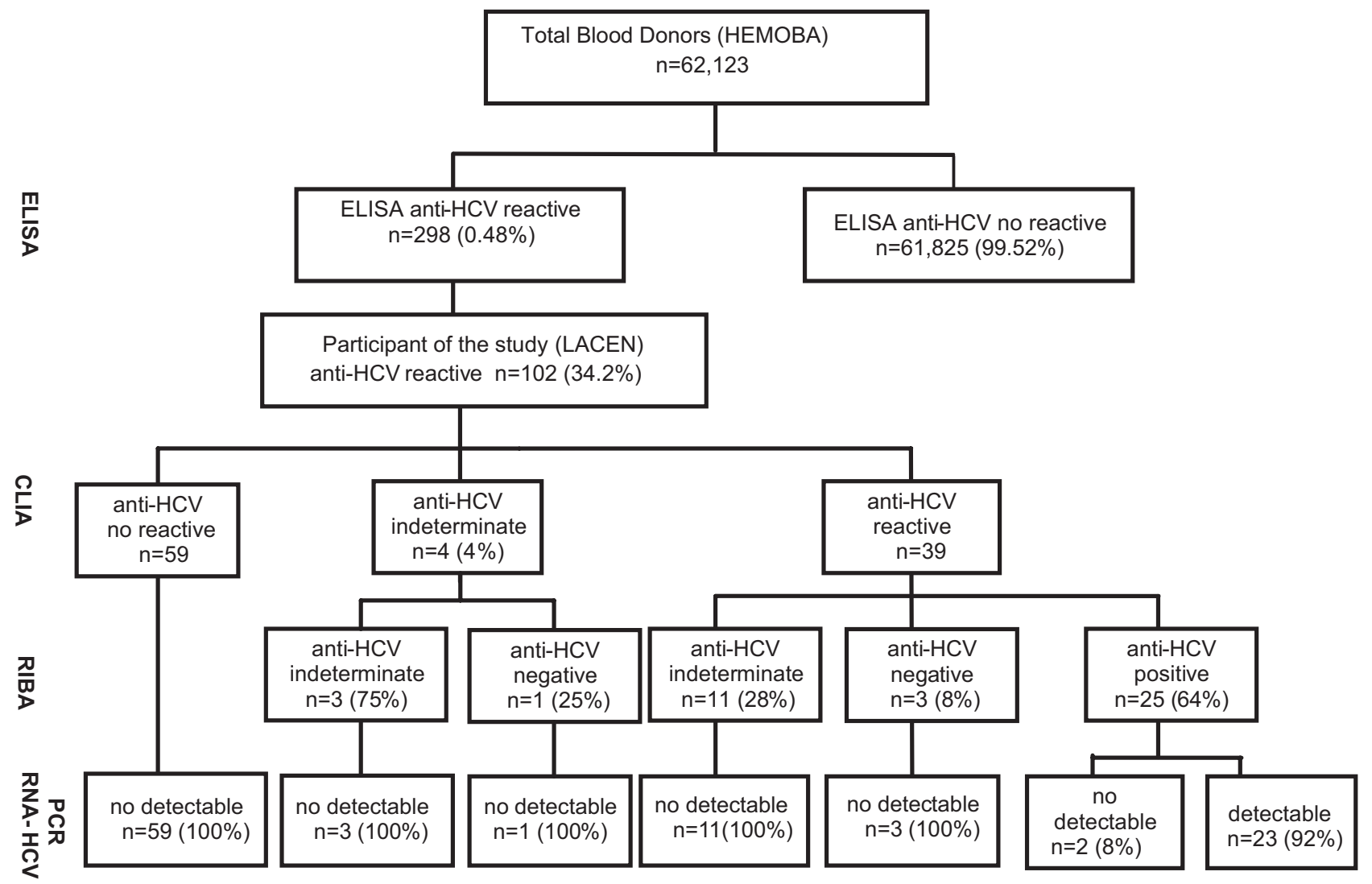

FIGURE 1 - Flowchart: Prevalence of anti-HCV blood donors: June 1, 2009 - December 22, 2010. ELISA: enzyme linked immuno sorbent assay; CLIA: chemiluminescence assays; RIBA: recombinant immunoblot assay. PCR: polymerase chain reaction; RNA-HCV: ribonucleic acid-hepatitis C virus; HEMOBA: Hemotherapy Foundation of Bahia. LACEN: Laboratório Central de Saúde Pública. 
in accordance with manufacturer guidelines. The samples were considered positive for anti-HCV antibodies when the index values $(\mathrm{S} / \mathrm{CO})$ were $>1.1$, non-reactive when values were $<0.9$ and indeterminate when values ranged between 0.9 and 1.1.

The samples with positive and indeterminate results for anti-HCV were further assessed for anti-HCV antibodies using a RIBA 3.0 Strip Immunoblot Assay (Chiron RIBA HCV 3.0 SIA, Chiron Corp., Emeryville, CA, USA).

\section{Molecular analysis}

The qualitative detection of HCV-RNA was performed using the AMPLICOR ${ }^{\circledR}$ Hepatitis C Virus (HCV) Test v2.0 (Roche Diagnostics Corp., Indianapolis, IN, USA) with a detection limit of $50 \mathrm{IU} / \mathrm{mL}$. Genotyping was performed using the VERSANT HCV Genotype 2.0 Assay (LiPA) (Siemens, Tarrytown, NY, USA) with a reverse hybridization method. HCV-RNA was quantified with either the AMPLICOR HCV MONITOR ${ }^{\circledR}$ Test v2.0 (Roche Diagnostics Corp., Indianapolis, IN, USA) using real-time PCR or the COBAS ${ }^{\circledR}$ AmpliPrep/COBAS ${ }^{\circledR}$ TaqMan $^{\circledR}$ HCV Test (Roche Diagnostics Corp., Indianapolis, IN, USA), which also utilizes RT-PCR. All tests were performed and analyzed in accordance with manufacturer guidelines.

\section{Statistical analysis}

All data obtained in this study were entered into the Epi Info $^{\mathrm{TM}}$ database v3.5.1, which is maintained by the Centers for Disease Control and Prevention (CDC, Atlanta, GA, USA). Statistical data analysis was performed using Epi Info v3.5.1. Results were considered statistically significant when the p-value $<0.05$.

\section{RESULTS}

A total of 102 blood samples were used to compare RIBA test results with those from standard HCV tests. The mean age of the blood donors was $37.9 \pm 10.1$ years, and $56.9 \%(58 / 102)$ of the donors were male. New blood samples were collected from each individual and submitted for retesting at LACEN-BA to detect anti-HCV using the ARCHITECT anti-HCV assay (Abbott Diagnostics, Wiesbaden, Germany). Of these samples,
$38.2 \%(39 / 102)$ were positive, $4 \%(4 / 102)$ were indeterminate and $57.8 \%(59 / 102)$ were negative for anti-HCV antibodies. Anti-HCV index values $\geq 5$ were most the common values $(61.5 \%, 24 / 39)$ observed. Table 1 delineates the classifications of all of the anti-HCV index values measured in this study.

RIBA testing was performed on 43 samples, including 39 positive and 4 indeterminate for anti-HCV antibodies using CLIA. Of the samples, $58.1 \%$ (25/43) were positive, $32.6 \%$ $(14 / 43)$ were indeterminate, and $9.3 \%$ (4/43) were negative. Of the positive RIBA samples, $60 \%$ (15/25) presented reactivity for all (4) antigens present on the nitrocellulose immunoblot test strips (Table 2). The observed reactivities for c100, c33, c22 and NS5 antigens in these RIBA-positive samples were $84 \%$, $100 \%, 96 \%$ and $68 \%$, respectively (Table 3 ).

Of the 14 samples that were indeterminate by RIBA, reactivity was observed in the $\mathrm{c} 33(86 \% ; 12 / 14)$ and c $22(14 \%$; $2 / 14)$ bands, with the following band intensity levels: $1+(50 \%$; $7 / 14), 2+(14 \% ; 2 / 14)$ or $3+(36 \% ; 5 / 14)$. No reactivity was detected in the c100 and NS5 bands in these samples.

RIBA was repeated six months later on some of the individuals who received an indeterminate initial RIBA result $(71.4 \%$; $10 / 14)$. Of these individuals, only two received negative results, while all of the other results remained indeterminate. Similar band patterns were observed in these samples, and $50 \%(4 / 8)$ of the samples were considered weak for band intensities $(1+$ or $2+)$.

HCV-RNA was successfully detected using qualitative PCR in $92 \%$ (23/25) of the RIBA-positive samples. Of the two positive RIBA samples that had no detectable HCV-RNA, one sample presented reactivity in bands c100, c22 and c33, while the other presented reactivity in bands c33 and NS5. The order of genotype prevalence was as follows: genotype $1(78.3 \%$; $18 / 23)$, genotype $3(17.4 \% ; 4 / 23)$ and genotype $2(4.3 \% ; 1 / 23)$ (Table 3). HCV-RNA was undetectable in all of the samples with indeterminate or negative RIBA results, and the HCV viral load was quantified in each sample with detectable HCV-RNA, as shown in Table 1.

Of the samples with viral loads $>850,000 \mathrm{IU} / \mathrm{mL}$ (56.5\%; $13 / 23$ ), eight samples presented reactivity to the four antigens (c100, c33, c22 and NS5) evaluated using RIBA, while four

TABLE 1 - Comparison of RIBA test results, anti-HCV index values and HCV-RNA.

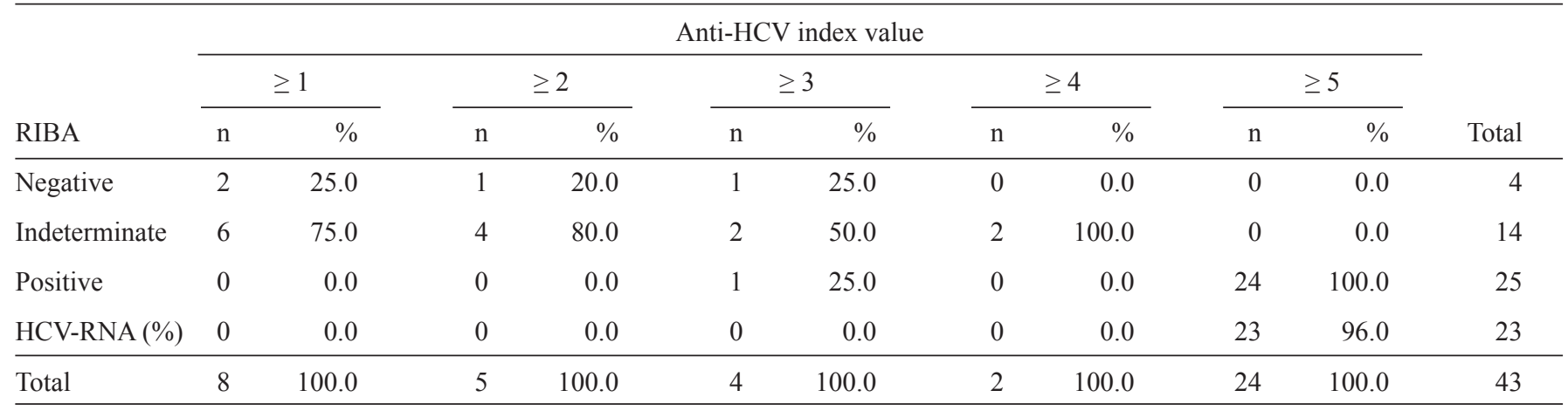

HCV-RNA: Hepatitis C virus-ribonucleic acid; RIBA: recombinant immunoblot assay. 
TABLE 2 - Frequency of positive bands observed in RIBA testing.

\begin{tabular}{lcc}
\hline Number of positive RIBA bands & $\begin{array}{c}\text { Absolute } \\
\text { frequency (n) }\end{array}$ & $\begin{array}{c}\text { Relative } \\
\text { frequency (\%) }\end{array}$ \\
\hline $1 *$ & 14 & 36.0 \\
2 & 3 & 8.0 \\
3 & 7 & 18.0 \\
4 & 15 & 38.0 \\
\hline Total & 39 & 100.0 \\
\hline
\end{tabular}

*RIBA indeterminate. RIBA: recombinant immunoblot assay. samples had reactivity in three out of four bands and one sample reacted in just two of the bands. In the samples with viral loads $<850,000 \mathrm{IU} / \mathrm{mL}(43.5 \% 10 / 23)$, seven had reactivity in all four bands, two presented reactivity in three bands and one presented reactivity in just two bands. The lowest viral load detected in this study was $30,200 \mathrm{IU} / \mathrm{mL}$, with reactivity observed in bands c33 and c22 using RIBA; accordingly, the highest viral load observed was $69,000,000 \mathrm{IU} / \mathrm{mL}$, with reactivity evidenced against all four antigens. The number of bands present on the immunoblot strips and the observed reactivity patterns using RIBA were subsequently correlated with the presence of HCVRNA and genotype, as shown in Table 3.

TABLE 3 - Comparison of detected antigens, presence of viremia and HCV genotypes in RIBA-positive samples.

\begin{tabular}{|c|c|c|c|c|c|c|c|c|c|c|c|}
\hline \multirow{2}{*}{$\begin{array}{l}\text { Number of bands } \\
4\end{array}$} & \multicolumn{4}{|c|}{ RIBA test antigens } & & & & & \multicolumn{3}{|c|}{ HCV genotype } \\
\hline & $\frac{\mathrm{c} 100}{+}$ & $\frac{\mathrm{c} 33}{+}$ & $\frac{\mathrm{c} 22}{+}$ & $\frac{\mathrm{NS} 5}{+}$ & 15 & 60.0 & 15 & 65.0 & 13 & 0 & 2 \\
\hline \multirow[t]{2}{*}{3} & + & + & + & - & 6 & 24.0 & 5 & 22.0 & 4 & 0 & 1 \\
\hline & - & + & + & + & 1 & 4.0 & 1 & 4.0 & 0 & 1 & 0 \\
\hline Total (n) & 21 & 25 & 24 & 17 & \multicolumn{2}{|c|}{25} & \multicolumn{2}{|c|}{23} & 18 & 1 & 4 \\
\hline$(\%)$ & 84.0 & 100.0 & 96.0 & 68.0 & \multicolumn{2}{|c|}{100.0} & \multicolumn{2}{|c|}{100.0} & 78.3 & 4.3 & 17.4 \\
\hline
\end{tabular}

HCV-RNA: Hepatitis C virus-ribonucleic acid; RIBA: recombinant immunoblot assay

\section{DIsCusSION}

The presence of anti-HCV antibodies was confirmed in only $38.2 \%$ (39/102) of 102 individuals with positive anti-HCV results using CLIA at LACEN-BA. The discrepancy between the results obtained at HEMOBA and the results from this study may be largely explained by the use of different serological diagnostic testing techniques for $\mathrm{HCV}$ detection. Blood banks generally employ extremely sensitive testing methods to avoid the risk of HCV transmission via transfusion, while public health laboratories use tests that offer improved specificity.

In low-risk populations, such as blood donors, HCV screening lacks specificity, as approximately $60 \%$ of reagent samples return false-positive results ${ }^{11}$. These false-positive anti-HCV results may be the product of cross-reactivity with immunoglobulins that are present in populations of African descent or in individuals with myeloma, rheumatoid factor, liver diseases (such as cirrhosis and cancer), autoimmune diseases (collagenous, autoimmune hepatitis) or other viral infections (such as HIV or hepatitis B). False positives may also result when serum samples are stored for extended periods, when serum samples are subjected to temperature variations or when an individual has received prior immunization ${ }^{12}$.
In this study, HCV was detected in $53.5 \%(23 / 43)$ of the participants who tested positive or indeterminate for anti-HCV antibodies. This detection level represented a lower percentage than that of a study conducted in blood donors from Midwestern Brazil, which reported HCV detection in $80.5 \%$ (165/205) of subjects who were positive for anti-HCV (using ELISA) ${ }^{13}$. In $92 \%(23 / 25)$ of the RIBA-positive samples in which HCV-RNA was detected and the corresponding anti-HCV index value was $>5.0$, a statistically significant association was observed between elevated anti-HCV index values and the presence of HCV-RNA (p-value $<0.01$ ). Indeterminate results were observed in $32.6 \%$ (14/43) of the samples submitted to RIBA, which is in contrast with the lower percentage of indeterminate RIBA samples that was previously reported ${ }^{14}$.

In samples that were considered positive or indeterminate $(18.6 \%, 19 / 102)$ and that had anti-HCV index value $(\mathrm{S} / \mathrm{CO})<5.0$ (i.e., those indicating low positivity), $73.7 \%$ (14/19) had RIBA-indeterminate results. In addition, eleven samples presented antibodies that bound to antigen c33, while three samples had antibodies that bound to c22. HCV-RNA was not detectable in any of these samples, which is consistent with results that have been previously reported ${ }^{8,11,15,16}$. Nonetheless, in other studies ${ }^{17}$, the virus was successfully detected in some indeterminate RIBA samples. 
One plausible explanation for the low positivity observed herein with respect to anti-HCV antibodies and negative or indeterminate RIBA results with no detected viremia could involve instances in which past $\mathrm{HCV}$ infections occurred or were eliminated without total elimination of the antibodies ${ }^{11,18}$. In this regard, several strategies have been employed to clarify the significance of indeterminate RIBA results in the absence of HCV-RNA, including risk factor analysis, alanine aminotransferase levels, anti-HCV index values, previous blood donations and reactivity intensity (detected in a single band using confirmatory immunoblot assay testing $)^{17,19}$.

Of the $71.4 \%(10 / 14)$ of samples that initially received an indeterminate RIBA result and that were submitted to retesting six months later, eight had similar results, with identical band patterns and undetectable HCV-RNA, while two had negative results using subsequent confirmatory RIBA testing. These findings are consistent with data that have been presented previously ${ }^{17,20}$.

The present study found no correlation between viral load and the number of positive bands observed using RIBA analysis, despite the HCV viral load being high in $65 \%(15 / 23)$ of the samples that showed reactivity in all four bands. In the samples demonstrating reactivity in two bands (c33 and c22), viral load was detected in just two. It was not possible to confirm any relationship between the presence of viremia and the number of bands with observed reactivity using RIBA due to the insufficient sample size employed in this study and the low frequency of viremia detected in positive RIBA samples with reactivity in two bands, which indicated the elimination of $\mathrm{HCV}$ infection ${ }^{21}$.

The most prevalent genotype observed in this study was genotype 1 , followed by genotype 3 , which is in agreement with previous findings ${ }^{22,23}$. The presence of all four bands in the genotype 1 samples may be explained by the increased prevalence of this genotype in the present study and the fact that the proteins considered by the RIBA nitrocellulose test strips pertain to this genotype.

Indeterminate RIBA results were reported in $13.7 \%(14 / 102)$ of the samples obtained from the individuals included in this study, indicating the need for molecular testing as a confirmatory measure in the diagnosis of $\mathrm{HCV}$ infection. All of these samples had anti-HCV index values $<5.0$ and undetectable HCV-RNA, and $64 \%(9 / 14)$ of the samples showed weak band intensity $(1+$ or $2+)$. However, individuals who received positive RIBA results with the presence of viremia had anti-HCV index values $>5.0$ and strong band intensity $(3+$ or $4+)$. In conclusion, in individuals with indeterminate RIBA test results, it is highly likely that $\mathrm{HCV}$ RNA will be undetectable when the detection limit is $50 \mathrm{IU} / \mathrm{mL}$.

\section{ACKNOWLEDGMENTS}

The authors would like to thank the Hematology and Hemotherapy Foundation of Bahia (HEMOBA), the Central Laboratory of Public Health of Bahia (LACEN-BA) and Janet Lindow, reviewer.

\section{CONFLICT OF INTEREST}

The authors declare that there is no conflict of interest.

\section{FINANCIAL SUPPORT}

This study was supported by the Brazilian National Council for Scientific and Technological Development (CNPq), Grant no. 4003071/2004-6, and the Program for Centers of Excellence (PRONEX), Grant no. 08282/07.

\section{REFERENCES}

1. Alter MJ. Epidemiology of hepatitis $\mathrm{C}$ virus infection. World J Gastroenterol 2007; 13: 2436-2441.

2. Ministério da Saúde. Secretaria de Vigilância em Saúde. Departamento de Vigilância Epidemiológica. Hepatites virais: o Brasil está atento. Brasília: Ministério da Saúde; 2008.

3. Zarife MA, Silva LK, Silva MB, Lopes GB, Barreto ML, Teixeira Mda G, et al. Prevalence of hepatitis $C$ virus infection in north-eastern Brazil: a population-based study. Trans R Soc Trop Med Hyg 2006; 100:663-668.

4. Contreras A. Anticuerpo a hepatitis C: verdadero o falso positive? Nuevas estratégias de diagnóstico. Rev Invest Clín 2006; 58:153-160.

5. Kim S, Kim JH, Yoon S, Park YH, Kim HS. Clinical performance evaluation of four automated chemiluminescence immunoassays for hepatitis C virus antibody detection. J Clin Microbiol 2008; 46:39193923.

6. Ghany MG, Strader DB, Thomas DL, Seeff LB. Diagnosis, management, and treatment of hepatitis C: an update. Hepatology 2009; 49:1335-1374.

7. Pawlotsky JM. Diagnostic tests for hepatitis C. J Hepatol 1999; 31:71-79.

8. Contreras AM, Tornero-Romo CM, Toribio JG, Celis A, OrozcoHernandez A, Rivera PK, et al. Very low hepatitis C antibody levels predict false-positive results and avoid supplemental testing. Transfusion 2008; 48:2540-2548

9. Souto FJ, Ribeiro LC, Perazolo GF, Fortes HM, Saldanha AA. Immunoblot as a supplemental test to detect antibodies to hepatitis $\mathrm{C}$ virus in blood donors. Rev Soc Bras Med Trop 2002; 35:69-71.

10. Alter MJ, Kuhnert WL, Finelli L. Guidelines for laboratory testing and result reporting of antibody to hepatitis C virus. MMWR 2003; 5:1-13.

11. Bes M, Esteban JI, Casamitjana N, Piron M, Quer J, Cubero M, et al. Hepatitis C virus (HCV)-specific T-cell responses among recombinant immunoblot assay-3-indeterminate blood donors: a confirmatory evidence of HCV exposure. Transfusion 2009; 49:1296-1305.

12. Colin C, Lanoir D, Touzet S, Meyaud-Kraemer L, Bailly F, Trepo C. Sensitivity and specificity of third-generation hepatitis $\mathrm{C}$ virus antibody detection assays: an analysis of the literature. J Viral Hepatitis 2001; 8: 87-95.

13. Martins RM, Teles SA, Freitas NR, Motta-Castro AR, Souto FJ, Mussi A, e al. Distribution of hepatitis $C$ virus genotypes among blood donors from mid-west region of Brazil. Rev Inst Med Trop Sao Paulo 2006; 48:53-55.

14. Kesli R, Ozdemir M, Kurtoglu MG, Baykan M, Baysal B. Evaluation and comparison of three different anti-hepatitis $\mathrm{C}$ virus antibody tests based on chemiluminescence and enzyme-linked immunosorbent assay methods used in the diagnosis of hepatitis $\mathrm{C}$ infections in Turkey. J Int Med Res 2009; 37:1420-1429.

15. Rios M, Diago M, Rivera P, Tuset C, Cors R, Garcia V, et al. Epidemiological, biological and histological characterization of patients with indeterminate third-generation recombinant immunoblot assay antibody results for hepatitis C virus. J Viral Hepatitis 2006; 13: 177-181. 
16. Cavazza $S$, Lagging $M$. Indeterminate third-generation hepatitis $C$ recombinant immunoblot assay and HCV RNA analysis: isolated reactivity against NS5 associated with $\mathrm{HCV}$ viraemia in clinical patients but not blood donors. Scand J Infect Dis 2005; 37:488-492.

17. Kiely P, Kay D, Parker S, Piscitelli L. The significance of thirdgeneration HCV RIBA-indeterminate, RNA-negative results in voluntary blood donors screened with sequential third-generation immunoassays. Transfusion 2004; 44:349-358.

18. Dufour DR, Talastas M, Fernandez MD, Harris B. Chemiluminescence assay improves specificity of hepatitis $\mathrm{C}$ antibody detection. Clinical Chem 2003; 49:940-944.

19. Pawlotsky JM, Bastie A, Pellet C, Remire J, Oisedarthuy F, Wolfe L, et al. Significance of Indeterminate Third-Generation Hepatitis C Virus Recombinant Immunoblot Assay. J Clin Microbiol 1996; 34:80-83.
20. Piro L, Solinas S, Luciani M, Casale A, Bighiani T, Santonocito D, et al. Prospective study of the meaning of indeterminate results of the recombinant immunoblot assay for hepatitis $\mathrm{C}$ virus in blood donors. Blood Transf 2008; 6:107-111.

21. Dow BC, Buchanan I, Munro H, Follett EA, Davidson F, Prescott LE, et al. Relevance of RIBA-3 supplementary test to HCV PCR positivity and genotypes for HCV confirmation of blood donors. J Med Virol 1996; 49:132-136.

22. Silva MB, Andrade TM, Silva LK, Rodart IF, Lopes GB, Carmo TM, et al. Prevalence and genotypes of hepatitis $C$ virus among injecting drug users from Salvador-BA, Brazil. Mem Inst Oswaldo Cruz 2010; 105:299-303.

23. Torres KL, Malheiro A, Tateno A, de-Lima TA, Viana-Maia LP, DinizPimentel JP, et al. Hepatitis C virus in blood donors, Brazil. Emerg Inf Dis 2009; 15:676-678. 